\title{
EFFECTIVENESS OF STRUCTURED TEACHING PROGRAMME REGARDING HEALTH HAZARDS OF JUNK FOOD AMONG ADOLESCENTS
}

\author{
Mrs. Shalini* \& Dr. Rajesh Konnur**
}

*Ph.D., Scholar, Himalayan University, Itanagar, Arunachal Pradesh, India.

** Professor, College of Nursing, Kurji Holy Family Hospital, Patna, Bihar, India. DOI: http://doi.org/10.47211/trr.2019.v05i02.012

Received $20^{\text {th }}$ November 2019, Accepted $6^{\text {th }}$ December 2019, Published $20^{\text {th }}$ December 2019

\begin{abstract}
"Junk food" generally refers to foods that contain lot of calories with little nutritional value. Adolescents suddenly seem to have stepped into a world of fast food and vending machines, totally unaware of havoc they are creating for themselves. Adolescents are at greater risk for nutritional problem both from physiological and psychological standpoint. Most of the adolescents have little knowledge about health hazards of junk foods. This global problem of consuming junk food on a large scale and its impact on health needs emphasis and health education which can greatly contribute to its limited consumption and switching over to healthy eating habits for the better living. Knowledge highlighting about the eating habits, nutritional aspects, and quality of unhealthy foods, their health impact and preventive measures should be given to create awareness and render health education for a change towards good eating practices. Junk food and its impact on health have been reviewed from various resources, so as to emphasize its ill effects and measures to be adapted towards healthy living.
\end{abstract}

Key Words: Structured teaching programme, junk food adolescent.

\section{ABOUT AUTHORS:}

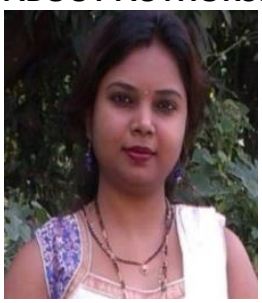

The author Mrs Shalini is Ph.D., Scholar in Himalayan University, Itanagar, Arunachal Pradesh, India.

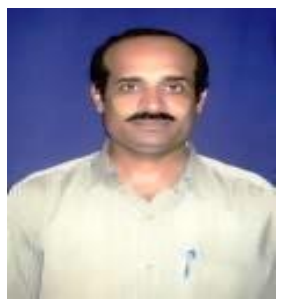

Author Dr. Rajesh G Konnur Associate Professor, KHFHCON, Patna, Bihar, India. He has been awarded Bhartia Shikha Ratan award - 2007 for "individual achievements and national development" by the economic for health and educational growth." New Delhi. Shikha Bharati award - 2007 for Excellency in education by Indian achievers forum. New Delhi. He has presented more than 25 papers in various conferences. 


\section{INTRODUCTION}

Junk food is a term for food containing high levels of calories from sugar or fat with little protein, vitamins or minerals. The term implies that particular food has little "nutritional value" and contains excessive fat, sugar, salt, and calories. Junk foods are commercially prepared foods that are highly processed and pre- packaged. The availability of junk food and snacks at low prices and marketing strategies adapted by manufacturers of such foods has triggered an evolution wherein, consumption of foods that require neither the structure nor the preparation of a formal meal. It seems to have engulfed every age; every race and the newest entrants on stage are children, especially school going children and the adolescents. Many research studies show that consuming junk food is nutritional hazard and it only provides empty calories. This kind of food has no vitamins and minerals. Fast food is loaded with saturated fat and high calories, and is low in fiber and nutrients. When these types of foods are eaten, the body is forced to produce its own enzymes to convert the empty calories into usable energy. From this it is clear that junk foods will cause obesity and associated health hazards. In today's world scenario, junk food has become prominent feature of diet for adolescents. Eating frequent junk foods causes teens and young adults to gain more weight and they face an increased risk of developing obesity. The incidence of child obesity has more than tripled in the past 30 years. The prevalence of obesity among adolescents aged between 12 to 19 years has been increased from $5.0 \%$ to $18.1 \%$. Through health education, a change towards good eating practices and adaption of healthy living is possible.

\section{NEED FOR THE STUDY}

\section{"To eat is a necessity, but to eat intelligently is an art"}

-La Rochefoucauld Junk food is loaded with calories from refined sugar and fats (especially, the artery-clogging saturated and hydrogenated fats, which are repeatedly reheated to high temperatures for frying purposes). Another issue in the fast food industry is the health hazards that fast food are prone to. A particular hazard is the E-coli bacteria that meat products are susceptible to. Eating fast food and sedentary lifestyle leads to obesity. Obesity leads to other complications like increase in the cholesterol level, blocking of the arteries, the increased risk of coronary diseases, in addition to the general physical discomfort posed by the extra weight. Fast food is also addictive, it is very difficult to give up on their greasy, fatty foods and carbonated drinks and switch to healthier options. It is clear that eating too much of junk foods can lead to various health issues. According to the survey Indian fast food industry is growing by $40 \%$ every year and generates huge sales. India has become one of the biggest hubs for global fast food chains to grow due to the availability of raw materials, population size etc. Major global fast food players and its size Mc Donald's - 300 outlets and according to the plan it can 500 by the year 2020 . According to WHO, around $39 \%$ of the world population were overweight and $13 \%$ of the population was suffering from obesity, in 2014. It was also identified by investigator's personal experience that consumption of junk foods is becoming more common especially among adolescents; they need to be informed about the ill effects or harmful hazards of junk foods on health. Hence the investigator felt there is a need to increase the level of knowledge of adolescents (boys and girls) regarding effects of junk foods on health through structured teaching programme.

\section{PROBLEM STATEMENT}

"A study to assess the Effectiveness of Structured Teaching Programme on Knowledge regarding the health hazards of junk foods among adolescents (13-15 years) in selected schools of Patna, Bihar".

\section{OBJECTIVES}

1. Knowledge of adolescents regarding the health hazards of junk foods among adolescents.

2. Effectiveness of STP on knowledge regarding the health hazards of junk food among adolescents.

\section{RESAERCH METHODOLOGY}

RESEARCH APPROACH- Quantitative Evaluative Approach

RESEARCH DESIGN- Quasi Experimental Research Design

SETTING OF THE STUDY- Private schools of Patna, Bihar.

POPULATION- Adolescents between 13-15years who are studying in the Private schools of Patna.

SAMPLE AND SAMPLING TECHNIQUE

SAMPLE- Adolescents between the age group of 13-15 years who were studying in various private schools of Patna, Bihar.

SAMPLE SIZE- 500 adolescents between the age group of $13-15$ years who were studying in various Private schools of Patna, Bihar. 


\section{ARTICLES}

SAMPLE TECHNIQUE- Simple random sampling technique

DEVELOPMENT OF TOOL- Based on objectives, a structured knowledge questionnaire was prepared to assess the knowledge regarding the health hazards of junk foods among the adolescents (13-15years), Patna , Bihar.

FINDINGS OF THE STUDY

Objective 1: Findings related to assessment of level of knowledge score

Table 1.1

Assessment of level of knowledge score

$\mathrm{N}=500$

Table 1.1 shows that the level of knowledge regarding health hazards of junk food. In Pre-test knowledge

\begin{tabular}{|l|l|l|l|l|l|l|}
\hline \multirow{2}{*}{$\begin{array}{l}\text { Level } \\
\text { Knowledge }\end{array}$} & \multicolumn{2}{|l|}{$\begin{array}{l}\text { Total } \\
\% a g e\end{array}$} & Pre test & \multicolumn{2}{l|}{ Post test } \\
\cline { 4 - 7 } & & & $\begin{array}{l}\text { Frequency } \\
\text { (f) }\end{array}$ & $\begin{array}{l}\text { Percentage } \\
\text { (\%) }\end{array}$ & $\begin{array}{l}\text { Frequency } \\
\text { (f) }\end{array}$ & $\begin{array}{l}\text { Percentage } \\
\text { (\%) }\end{array}$ \\
\hline Poor & Grading & & 197 & 39.4 & 131 & 26.2 \\
\hline Average & $0-12$ & $0-25 \%$ & 303 & 60.6 & 369 & 73.8 \\
\hline Good & $13-25$ & $26 \%-50 \%$ & 0 & 0 & 0 & 0 \\
\hline Very Good & $26-37$ & $51 \%-75 \%$ & 0 & 0 & 0 & 0 \\
\hline
\end{tabular}

303(60.6\%) were having average knowledge and 197(39.4\%) were having the poor knowledge but no one was having good knowledge and very good knowledge. In post-test knowledge score the average score was $369(73.8 \%)$ and poor knowledge was $131(26.2 \%)$ and no one was having the good knowledge and very good knowledge.

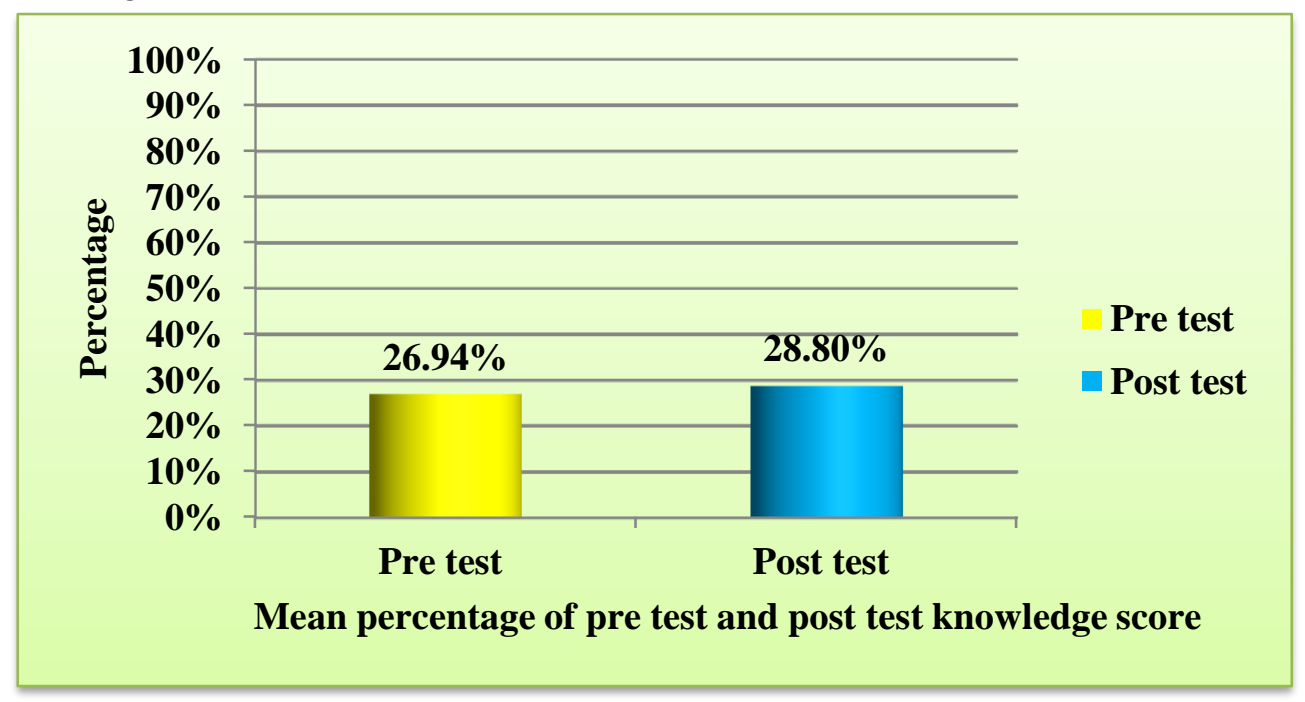

Figure 1.1: Cylindrical diagram shows the mean percentage of pre-test and post-test knowledge score.

The data represented in table1.2 and Figure no.1.1 shows that the mean pre-test knowledge score was less i.e.13.47 and mean percentage was $26.94 \%$ than the mean post knowledge score which is 14.4 and mean percentage was $28.8 \%$. It shows that there was increase in the post-test knowledge score.

Objective 2: Findings related to assessment of effectiveness of STP on knowledge score

Table 2.1

Paired' $t$ ' table for assessing the effectiveness of structured teaching programme on knowledge score

$$
\mathrm{N}=500
$$

\begin{tabular}{|l|l|l|l|l|l|l|}
\hline & Range & Mean & SD & $\begin{array}{l}\text { Mean } \\
\text { Difference }\end{array}$ & Paired t test & Remark \\
\cline { 1 - 5 } Pre- test & $8-22$ & 13.47 & 3.69112 & 0.93 & $10.678^{* *}$ & Significant \\
\cline { 1 - 4 } & $8-22$ & 14.4 & 3.47738 & & \\
\hline
\end{tabular}

$\mathrm{t}_{(499)}=1.965$ at $\mathrm{p} \leq 0.05$ significance level, * Significant

The data represented in table 2.1 shows that the mean pre-test score was 13.47 and mean post-test score was 14.4 and the and the mean difference was 0.93 . The Paired ' $t$ ' value was 10.678 which is higher than the table value and was significant. It shows there was effectiveness of structured teaching programme. 
Table 2.2

Paired ' $t$ ' table for assessing the effectiveness of STP on area wise knowledge score

\begin{tabular}{|c|c|c|c|c|c|c|c|}
\hline & Area & Range & Mean & SD & $\begin{array}{l}\text { Mean } \\
\text { difference }\end{array}$ & $\begin{array}{l}\text { Paired } t \\
\text { test }\end{array}$ & Remark \\
\hline Pre- test & \multirow{2}{*}{$\begin{array}{lrr}\text { JUNK } & \text { FOOD } & \text { AND } \\
\text { CONSUMPTION } & \text { OF } \\
\text { JUNK FOOD } & \\
\end{array}$} & $2-8$ & 5.702 & 1.73644 & \multirow[b]{2}{*}{0.4} & \multirow{2}{*}{$6.587^{*}$} & \multirow{4}{*}{ Significant } \\
\hline Post- test & & $2-10$ & 6.102 & 2.07272 & & & \\
\hline Pre- test & \multirow{2}{*}{$\begin{array}{l}\text { HEALTH HAZARDS } \\
\text { OF JUNK FOODS }\end{array}$} & 3-15 & 7.768 & 3.23343 & \multirow{2}{*}{0.53} & \multirow{2}{*}{$7.692 *$} & \\
\hline Post- test & & $3-15$ & 8.298 & 3.31832 & & & \\
\hline
\end{tabular}

$\mathrm{t}_{(499)}=1.965$ at $\mathrm{p} \leq 0.05$ significance level,$*$ Significant

The data represented in table 2.2 shows area wise knowledge regarding health hazards of junk food. In pretest, Junk food and consumption of junk food the mean score is 5.702 and the post-test the mean score was 6.102 and mean difference was 0.4 and Paired ' $t$ ' test was 6.587 which is significant at 0.05 level of significance. Related to health hazards of junk food the Pre-test mean score was 7.768 and the post-test mean score was 8.298 and the mean difference was 0.53 and Paired ' $t$ ' test was 7.692 which is significant at 0.05 level of significance.

\section{RECOMMENDATIONS}

1. A similar study can be conducted on the larger scale.

2. A survey study can be done to determine the health hazards among adolescents.

3. A similar study can also be done on parents regarding their knowledge about the health hazards of junk foods.

4. Teaching programmes or awareness programme can be conducted in schools and community regarding prohibition of fast food advertisements and consumption.

5. Education of school children with audio visual aids on the harmful of effects of this junk food eating is highly recommended.

CONCLUSION: Based on the findings of the study it can be concluded that there was increase in the knowledge scores in all the areas included in the study after administration of knowledge questionnaire and structured teaching programme. Thus it was proved that STP was effective for creating awareness regarding health hazards of junk foods among adolescents of selected schools of Patna, Bihar.

\section{REFERENCES}

1. Yousuf Andlleb. (2017). A study to assess the effectiveness of planned teaching programme on knowledge regarding effects of junk foods on health among adolescents in selected schools of Srinagar. International Journal of Nursing Research. 3(4), 145-151.

2. Patel Brijesh. (2018). Assess the knowledge regarding ill effects of junk foods among students. Journal Nursing Today. 7 (1), 87-89.

Available from: www.joint.com

3. Rajan .K. Jinu. (2018). Effectiveness of Planned Teaching Programme on health hazards of junk food among adolescents. International Journal of Pediatric Nursing. 2(1), 5-15. Available from: www.rfppl.co.in

4. Saranya. (2016). Adolescent's knowledge regarding the effects of fast food on health. International Journal of Current Medical Research. 5(3), 406-409.

Retrieved from: http://www.wrpjournals.com

5. Rev. Dr. Abraham Mathew. (2019). Health Action, Dietary, 32, 3-6.

6. Dr. George Alex. (2004). Health action on Junk Foods (A growing health hazard).5-21.

7. Dr. Pajarer kumar Rajan. (2015). Nursing Digest. 3,13-15.

8. https://www.sciencedirect.com/science/article/pii/ 